\title{
Diuretic activity of the aqueous crude extract and solvent fractions of the leaves of Thymus serrulatus in mice
}

\author{
Amelework Eshetu Melka' \\ Eyasu Makonnen' \\ Asfaw Debella ${ }^{2}$ \\ Netsanet Fekadu² \\ Bekesho Geleta ${ }^{2}$ \\ 'Department of Pharmacology, \\ School of Medicine, College of Health \\ Sciences, Addis Ababa University, \\ Addis Ababa, Ethiopia; ${ }^{2}$ Directorate \\ of Traditional and Modern Medicine \\ Research, Ethiopian Public Health \\ Institute, Addis Ababa, Ethiopia
}

This article was published in the following Dove Press journal:

Journal of Experimental Pharmacology

31 October 2016

Number of times this article has been viewed
Correspondence: Bekesho Geleta Directorate of Traditional and Modern Medicine Research, Ethiopian Public Health Institute, P.O. Box 1242, Addis Ababa, Ethiopia

Tel +25I 91 1091969

Email bekeshog@gmail.com

\begin{abstract}
The present study was undertaken to investigate the diuretic activity and acute toxicity profile of the crude aqueous extract and solvent fraction of the leaves of Thymus serrulatus in saline-loaded Swiss albino mice. Mice of either sex were divided into six groups (five animals in each group). The control group received normal saline $(25 \mathrm{~mL} / \mathrm{kg})$, while the reference group received hydrochlorothiazide $(10 \mathrm{mg} / \mathrm{kg})$. Group III to Group VI received the test substances at dose levels of $125,250,500$, and $1,000 \mathrm{mg} / \mathrm{kg}$ orally, respectively. At the end of the fifth hour, urine was collected, and total volume of urine excreted by each animal was recorded. Concentrations of urinary $\mathrm{Na}^{+}$and $\mathrm{K}^{+}$were determined, and the $\mathrm{Na}^{+} / \mathrm{K}^{+}$ratio was calculated to make comparison among the groups. The acute toxicity of the most active fraction was also evaluated. The findings demonstrated that the crude aqueous extract of $T$. serrulatus leaves showed significant diuretic $(P<0.01)$, natriuretic $(P<0.01)$, and kaliuretic $(P<0.01)$ effects. At the dose of $1,000 \mathrm{mg} / \mathrm{kg}$, the $n$-butanol fraction demonstrated the highest diuretic activity comparable to the reference drug. It also showed a good natriuretic activity. The dichloromethane fraction, however, did not have significant diuretic activity. Both the crude aqueous extract of the leaves of T. serrulatus and its $n$-butanol fraction have diuretic activity with high concentration of urinary electrolytes in mice. Further studies, however, need to be pursued on the possible mechanism(s) of diuretic action.

Keywords: Thymus serrulatus, diuretic activity, electrolyte excretion, $\mathrm{Na}^{+} / \mathrm{K}^{+}$ratio
\end{abstract}

\section{Introduction}

Traditional medicine is a vital and often underestimated part of health care delivery services worldwide. It has a long and reputable history of use in the maintenance of health and in disease prevention and treatment, particularly for the management of chronic illnesses. ${ }^{1}$ Plants have been traditionally used as diuretics since time immemorial. ${ }^{2}$ Diuretics are drugs that increase urine output. They are used in edematous conditions such as cardiac failure, cirrhosis, and nephritic syndrome that lead to fluid overload in the body. ${ }^{3}$ Diuretics are used as part of therapeutic strategies to control fluid overload manifesting as ankle swelling, ascites, and/or pulmonary edema, help balance fluid, and help shift fluid out of the interstitium, leading to significant symptomatic relief and improved health-related quality of life in patients. ${ }^{4}$

Majority of the available diuretics, such as the loop and thiazides, are associated with several adverse effects such as electrolyte abnormalities (hypokalemia, hyperuricemia, and hyponatremia), acid-base imbalance, metabolic abnormalities (hyperglycemia and hyperlipidemia), and acute hypovolemia. ${ }^{5}$ It is, therefore, imperative to search for a diuretic that is comparatively free from such untoward and sometimes devastating adverse effects. The leaves of Thymus serrulatus, a plant indigenous to Ethiopia, are extensively 
used as a diuretic agent in Ethiopian Folkmedicine. ${ }^{6}$ They are also used to add flavor to food and drinks as well as being an important condiment in the kitchen. Aside from their economic significance, Thymus species have a meaningful contribution as a remedy in different illnesses ranging from infectious to chronic disorders in Ethiopia. ${ }^{7}$ The plant is also employed for the treatment of cough, headache, hypertension, stomachache, earache, liver disease, and gonorrhea. ${ }^{8}$

No scientific reports exist concerning its diuretic activity to date. The aim of the present study was, therefore, to evaluate the diuretic activity of the crude aqueous extract of $T$. serrulatus and solvent fractions and to determine the acute toxicity of the most active fraction in a mouse model.

\section{Materials and methods Animals}

Healthy Swiss albino mice of either sex weighing 20-25 g were used for the study. All animals used for this study were bred in the animal breeding facility of the Ethiopian Public Health Institute (EPHI). They were allowed to acclimatize to laboratory conditions for a week before commencing the actual experimental sessions; all animals had free access to standard pellet diet and water. The laboratory conditions were maintained on a $12 / 12$ hours light/dark cycle, with an ambient temperature of $25^{\circ} \mathrm{C}$.

Ethics approval for this study was obtained from the Scientific and Ethical Review Committee of Ethiopian Public Health Institute. The animals were treated with care throughout the study period and were kept in a well-controlled area according to the National Guide for the Care and Use of Laboratory Animals.

\section{Grouping and dosing}

The animals were divided into six groups, each with five mice. Group I received $25 \mathrm{~mL} / \mathrm{kg}$ normal saline (NS) solution or $2 \%$ Tween 80 in NS (dichloromethane fraction) and served as control, Group II received $10 \mathrm{mg} / \mathrm{kg}$ hydrochlorothiazide (HCTZ), the standard diuretic drug. Groups III, IV, V, and VI received 125, 250, 500, and 1,000 mg/kg, respectively, of the test substances (aqueous crude extract, dichloromethane, and $n$-butanol fractions).

\section{Chemicals}

HCTZ tablets (Esidrix $25 \mathrm{mg}$; Novartis International AG, Basel, Switzerland), absolute methanol from Techno PharmChem (India), n-butanol from E. Merck (Darmstadt, Germany), and dichloromethane (Chromasolv, Sigma-Aldrich, Irvine, UK) were used. All the chemicals used in the study were purchased from reliable sources and were of analytical grade.

\section{Plant material}

The leaves of $T$. serrulatus were collected from the mountains of Debre Sina, $190 \mathrm{~km}$ North of Addis Ababa. The plant was identified by a taxonomist Dr Dawit Abebe at EPHI, and a voucher specimen (No. TS-2103) was deposited at the herbarium of Traditional and Modern Medicine Research Directorate of EPHI.

\section{Preparation of aqueous crude extract}

Three hundred fifty grams of the powdered leaves of T. serrulatus were soaked in hot distilled water with continuous shaking on an electric shaker for 1 hour. Then, the suspension was filtered through gauze and the filtrate lyophilized (Labconco, Kansas City, MO, USA) to give an amorphous powder. The extract was then collected in a vial and kept in silica gel desiccators until further use. The percentage yield was calculated to be $9.3 \%$.

\section{Fractionation of crude aqueous extract}

Twenty-five grams of aqueous crude extract was dissolved in 50 $\mathrm{mL}$ of warm distilled water. The suspension was shaken with 50 $\mathrm{mL}$ of dichloromethane three times to get the dichloromethane fraction and the aqueous residue. The aqueous residue was then shaken with $50 \mathrm{~mL}$ of $n$-butanol three times to obtain $n$-butanol fraction. The resulting fractions were oven dried at a temperature of $40^{\circ} \mathrm{C}$. The percentage yield was calculated to be $4.8 \%$ and $9.2 \%$ for dichloromethane and $n$-butanol, respectively.

\section{Screening for diuretic activity}

All extracts were screened for their diuretic activity using the Kau et al's ${ }^{9}$ method with some modification. The animals were placed in a standard metabolic cage. Food and water were withdrawn 18 hours prior to the experiment. All extracts were dissolved in NS solution to make the required concentrations and were administered orally by gavage.

The cumulative urine excreted was measured at the end of the fifth hour in all groups. The parameters taken were total urine volume and urinary concentration of $\mathrm{Na}^{+}$and $\mathrm{K}^{+}$. The ratio of urinary excretion in the test group to urinary excretion in the control group is used as a measure of the diuretic action for the given dose of a drug. As the diuretic action is prone to variability, a parameter known as diuretic activity was calculated. To obtain diuretic activity, the diuretic action of the test substance was compared to that of the standard drug in the test group. The ratio of urinary excretion in the test group and control group was expressed as "diuretic action", which was used to be the measure of degree of diuresis. ${ }^{10}$ Urinary excretion $(\mathrm{UE})=$ Total urinary output $\left(V_{\mathrm{o}}\right) \times 100$

Total liquid administered $\left(V_{\mathrm{i}}\right)$

Diuretic action $=$ Urinary excretion in test group $\left(\mathrm{UE}_{\mathrm{t}}\right)$ 
Urinary excretion in control group $\left(\mathrm{UE}_{\mathrm{c}}\right)$

Diuretic activity $=$ Diuretic action of test group $\left(\mathrm{DA}_{\mathrm{t}}\right)$

Diuretic action of standard drug $\left(\mathrm{DA}_{\mathrm{H}}\right.$

\section{Determination of urinary $\mathrm{Na}^{+}$and $\mathrm{K}^{+}$}

The content of urinary $\mathrm{Na}^{+}$and $\mathrm{K}^{+}$was determined using a flame photometer with Instrumentation Laboratory Model 243 (Instrumentation Laboratory, Delhomme, France).

\section{Acute toxicity study}

In this study, Swiss albino mice of either sex weighing between 20 and $25 \mathrm{~g}$ were divided into two groups having six animals each. Before the day of the experiment, the animals were deprived of food for 18 hours and water was given ad libitum. The control group received saline; the other group received a limited dose of $5,000 \mathrm{mg} / \mathrm{kg}$ of the $n$-butanol fraction of the aqueous crude extract orally. The animals were then observed continuously for 24 hours, with more attention paid to the first 4 hours to observe overt signs of morbidity and mortality. The animals were kept under observation for up to 14 days thereafter. ${ }^{11}$

\section{Phytochemical screening}

All extracts used for the in vivo study were subjected to phytochemical screening following methods described by Trease and Evans. ${ }^{12}$

The extracts along with negative controls were tested for the presence of alkaloids, saponins, polyphenols, flavonoids, terpenoids, anthraquinones, tannins, phytosterols, and glycosides as follows:

\section{Alkaloids}

One and half milliliter of $10 \% \mathrm{HCl}$ was added to $0.5 \mathrm{mg}$ of the extracts in a test tube. The mixture was heated for 20 minutes. It was then cooled and filtered. To $1 \mathrm{~mL}$ of the filtrate, five drops Mayer's and Dragendorff's reagents each were added. The formation of cream and orange colored precipitates, respectively, indicated the presence of alkaloids in the extracts.

\section{Saponins}

The Froth test was used to test for saponins. An aqueous solution of $0.5 \mathrm{mg}$ of the extract was vigorously shaken for 2 minutes in a test tube. Foam that persisted for 30 minutes and did not disappear upon warming was taken as an indication of the presence of saponin in the extract.

\section{Polyphenols (phenolic compounds)}

Three drops of a mixture of $1 \mathrm{~mL} 1 \% \mathrm{FeCl}_{3}$ and $1 \% \mathrm{~K}_{3} \mathrm{Fe}(\mathrm{CN})_{6}$ each were added to $2 \mathrm{~mL}$ of extracts. The formation of green or blue color was taken as an indication of the presence of polyphenols.

\section{Flavonoids}

To $2 \mathrm{~mL}$ of aqueous solution of the extract, four drops of $2 \%$ lead acetate solution was added. Development of yellow or orange color confirmed the presence of flavonoids.

\section{Terpenoids (ketonic)}

One milliliter of 2,4-dinitrophenylhydrazine solutions ( $0.5 \mathrm{~g}$ dissolved in $100 \mathrm{~mL}$ of $2 \mathrm{M} \mathrm{HCl}$ ) was added to $2 \mathrm{~mL}$ aqueous solution of the extract. The formation of yellow-orange coloration indicated the presence of ketonic terpenoids.

\section{Anthraquinones}

Borntrager's test: five milliliter of the extract was dried and shaken with $3 \mathrm{~mL}$ petroleum ether. The filtrate was added to $2 \mathrm{~mL}$ of a $25 \%$ ammonia solution. The mixture was shaken, and the formation of a red coloration was taken as an indication of the presence of free anthraquinones.

\section{Tannins}

Three drops of $5 \%$ ferric chloride solution was added to $1 \mathrm{~mL}$ of the extract solution in water. A greenish or blue coloration or precipitation was taken as an indication of the presence of tannins.

\section{Phytosterols and withanoids}

Five drops of $3 \%$ vanillin in concentrated $\mathrm{H}_{2} \mathrm{SO} 4$ was added to a concentrated chloroform solution of extracts. The formation of a rose or reddish brown color indicated the presence of anoids or phytosterols.

\section{Test for glycosides (Keller-Kiliani's test)}

To $0.5 \mathrm{~g}$ of each extract suspended in $5 \mathrm{~mL}$ water, $2 \mathrm{~mL}$ of glacial acetic acid containing one drop of ferric chloride hexahydrate $\left(\mathrm{FeCl}_{3} \cdot 6 \mathrm{H}_{2} \mathrm{O}\right)$ solution was added. This was mixed with $1 \mathrm{~mL}$ of concentrated $\mathrm{H}_{2} \mathrm{SO}_{4}$ and observed for a brown ring at the interface or a violet ring below the brown ring; alternatively, acetic acid was added and observed for a greenish ring above the brown ring, which gradually spread throughout this layer.

\section{Statistical analysis}

Results are expressed as mean \pm standard error of mean. Statistical analysis was performed using one-way ANOVA, and a $P$-value $<0.05$ was considered significant.

\section{Results}

\section{Urinary output}

The crude aqueous extract of $T$. serrulatus significantly increased the urine volume starting at a dose of $250 \mathrm{mg} / \mathrm{kg}$ as shown in Table 1. The highest urine output for the crude 
extract was observed at the highest dose $(1,000 \mathrm{mg} / \mathrm{kg})$ with an appreciable diuretic activity of $92 \%$ in comparison with the standard drug, HCTZ. The crude aqueous extract failed to show a significant urine output only at $125 \mathrm{mg} / \mathrm{kg}$, the lowest dose administered.

The dichloromethane fraction of the aqueous extract of $T$. serrulatus failed to exhibit a significant increase in urinary output at all given doses. Although there was a slight increment in the urine output, which was constant for the three test doses $(250,500$, and $100 \mathrm{mg} / \mathrm{kg})$, it was not statistically significant compared to the control. Moreover, there was an apparent reversal of presumed effect at the lowest dose, 125 $\mathrm{mg} / \mathrm{kg}$ (Table 2).

On the other hand, the $n$-butanol fraction significantly increased the urine output at all test doses. As shown in Table 3, even the lowest test dose of this fraction exhibited a significant $(P<0.05)$ diuretic activity of $70 \%$. The highest diuretic activity of the fraction was demonstrated at 1,000 $\mathrm{mg} / \mathrm{kg}$, which was about $94 \%$.

\section{Urinary electrolyte excretion}

The aqueous crude extract of $T$. serrulatus significantly increased the urinary excretion of $\mathrm{Na}^{+}$and $\mathrm{K}^{+}$at all given doses. Even though $1,000 \mathrm{mg} / \mathrm{kg}$ of the extract induced a statistically significant natriuresis $(P<0.01)$, it was less than the one induced by the standard drug HCTZ. The aqueous extract also induced significant kaliuresis at all doses (Table 4). Conversely, the dichloromethane fraction did not increase the urinary excretion of both $\mathrm{Na}^{+}$and $\mathrm{K}^{+}$at all doses (Table 5). The $n$-butanol fraction also significantly increased

Table I Effect of the crude aqueous extract of Thymus serrulatus on the urine volume in mice

\begin{tabular}{|c|c|c|c|c|}
\hline Treatment & $\begin{array}{l}\text { Cumulative } \\
\text { volume of } \\
\text { urine }(\mathrm{mL})\end{array}$ & $\begin{array}{l}\text { Urinary } \\
\text { excretion } \\
\left(V_{0} I V_{i}\right) \times 100 \\
\end{array}$ & $\begin{array}{l}\text { Diuretic } \\
\text { action } \\
\left(\mathrm{UE}_{\mathrm{t}} / \mathrm{UE}_{\mathrm{c}}\right) \\
\end{array}$ & $\begin{array}{l}\text { Diuretic } \\
\text { activity } \\
\left(\mathrm{DA}_{\mathrm{t}} / \mathrm{DA} \mathrm{A}_{\mathrm{H}}\right)\end{array}$ \\
\hline Control NS & $4.0 \pm 0.5 I$ & 80 & 1.0 & - \\
\hline $\begin{array}{l}\text { HCTZ } \\
10 \mathrm{mg} / \mathrm{kg}\end{array}$ & $6.25 \pm 0.86 * * *$ & 125 & 1.56 & 1.0 \\
\hline $\begin{array}{l}\text { T. serrulatus } \\
125 \mathrm{mg} / \mathrm{kg}\end{array}$ & $3.5 \pm 0.32$ & 87.5 & 1.09 & 0.69 \\
\hline $\begin{array}{l}\text { T. serrulatus } \\
250 \mathrm{mg} / \mathrm{kg}\end{array}$ & $5.25 \pm 0.97 *$ & 105 & 1.31 & 0.83 \\
\hline $\begin{array}{l}\text { T. serrulatus } \\
500 \mathrm{mg} / \mathrm{kg}\end{array}$ & $5 \pm 0.63 *$ & 90 & 1.12 & 0.71 \\
\hline $\begin{array}{l}\text { T. serrulatus } \\
1,000 \mathrm{mg} / \mathrm{kg}\end{array}$ & $5.75 \pm 0.84 * *$ & 115 & 1.44 & 0.92 \\
\hline
\end{tabular}

Notes: Cumulative values are expressed as mean \pm SEM. $* P<0.05, * * P<0.01$, $* * * P<0.001$.

Abbreviations: NS, normal saline; HCTZ, hydrochlorothiazide; SEM, standard error of mean.
Table 2 Effect of the dichloromethane fraction of aqueous extract of Thymus serrulatus on the urine volume in mice

\begin{tabular}{|c|c|c|c|c|}
\hline Treatment & $\begin{array}{l}\text { Cumulative } \\
\text { volume of } \\
\text { urine }(\mathrm{mL})\end{array}$ & $\begin{array}{l}\text { Urinary } \\
\text { excretion } \\
\left(V_{\mathrm{o}} / V_{\mathrm{i}}\right) \times 100\end{array}$ & $\begin{array}{l}\text { Diuretic } \\
\text { action } \\
\left(\mathrm{UE}_{\mathrm{t}} / \mathrm{UE}_{\mathrm{c}}\right)\end{array}$ & $\begin{array}{l}\text { Diuretic } \\
\text { activity } \\
\left(\mathrm{DA}_{\mathrm{t}} / \mathrm{DA}_{\mathrm{H}}\right)\end{array}$ \\
\hline $\begin{array}{l}\text { Control }(2 \% \\
\text { Tween } 80 \text { in } \\
0.9 \% \text { NS) }\end{array}$ & $3.5 \pm 0.15$ & 70 & 1.0 & - \\
\hline $\begin{array}{l}\mathrm{HCTZ} \\
10 \mathrm{mg} / \mathrm{kg}\end{array}$ & $6.25 \pm 0.21 * *$ & 125 & 1.79 & 1.0 \\
\hline $\begin{array}{l}\text { T. serrulatus } \\
125 \mathrm{mg} / \mathrm{kg}\end{array}$ & $3.0 \pm 0.08$ & 60 & 0.86 & 0.48 \\
\hline $\begin{array}{l}\text { T. serrulatus } \\
250 \mathrm{mg} / \mathrm{kg}\end{array}$ & $3.5 \pm 0.45$ & 70 & 1.0 & 0.55 \\
\hline $\begin{array}{l}\text { T. serrulatus } \\
500 \mathrm{mg} / \mathrm{kg}\end{array}$ & $4.0 \pm 0.75$ & 80 & 1.14 & 0.63 \\
\hline $\begin{array}{l}\text { T. serrulatus } \\
1,000 \mathrm{mg} / \mathrm{kg}\end{array}$ & $4.0 \pm 0.81$ & 80 & 1.14 & 0.63 \\
\hline
\end{tabular}

Notes: Cumulative values are expressed as mean \pm SEM for $n=5$. $* * P<0.01$. Abbreviations: NS, normal saline; HCTZ, hydrochlorothiazide; SEM, standard error of mean.

Table 3 Effect of the $n$-butanol fraction of aqueous extract of Thymus serrulatus on the urine volume in mice

\begin{tabular}{|c|c|c|c|c|}
\hline Treatment & $\begin{array}{l}\text { Cumulative } \\
\text { volume of } \\
\text { urine }(\mathrm{mL})\end{array}$ & $\begin{array}{l}\text { Urinary } \\
\text { excretion } \\
\left(V_{\mathrm{o}} / V_{\mathrm{i}}\right) \times 100\end{array}$ & $\begin{array}{l}\text { Diuretic } \\
\text { action } \\
\left(\mathrm{UE}_{\mathrm{t}} / \mathrm{UE}_{\mathrm{c}}\right)\end{array}$ & $\begin{array}{l}\text { Diuretic } \\
\text { activity } \\
\left(D_{t} / D A_{H}\right)\end{array}$ \\
\hline Control NS & $4.2 \pm 0.65$ & 84 & 1.0 & - \\
\hline HCTZ 10 mg/kg & $7.25 \pm 1.53 * * *$ & 14 & 1.7 & 1 \\
\hline $\begin{array}{l}\text { T. serrulatus } \\
125 \mathrm{mg} / \mathrm{kg}\end{array}$ & $5.0 \pm 0.47^{*}$ & 130 & 1.2 & 0.70 \\
\hline $\begin{array}{l}T . \text { serrulatus } \\
250 \mathrm{mg} / \mathrm{kg}\end{array}$ & $6.5 \pm 1.02^{* *}$ & 130 & 1.6 & 0.94 \\
\hline $\begin{array}{l}T . \text { serrulatus } \\
500 \mathrm{mg} / \mathrm{kg}\end{array}$ & $5.8 \pm 0.85^{*}$ & 116 & $\mathrm{I} .4$ & 0.82 \\
\hline $\begin{array}{l}\text { T. serrulatus } \\
1,000 \mathrm{mg} / \mathrm{kg}\end{array}$ & $6.7 \pm 0.71 * *$ & 134 & 1.6 & 0.94 \\
\hline
\end{tabular}

Notes: Cumulative values are expressed as mean \pm SEM. $* P<0.05, * * P<0.01$, $* * * P<0.001$.

Abbreviations: NS, normal saline; HCTZ, hydrochlorothiazide; SEM, standard error of mean.

Table 4 Effect of the crude aqueous extract of Thymus serrulatus on electrolyte excretion in mice

\begin{tabular}{|c|c|c|c|}
\hline \multirow[t]{2}{*}{ Treatment } & \multicolumn{3}{|c|}{ Electrolyte concentration (mEq/L) } \\
\hline & $\mathbf{N a}^{+}$ & $\mathbf{K}^{+}$ & $\mathrm{Na}^{+} / \mathrm{K}^{+}$ \\
\hline Control NS & $66.7 \pm 1.25$ & $45.2 \pm 1.21$ & 1.47 \\
\hline HCTZ 10 mg/kg & $|27.2 \pm 2.1| * * *$ & $54.4 \pm 1.09 * *$ & 2.33 \\
\hline T. serrulatus $125 \mathrm{mg} / \mathrm{kg}$ & $72.0 \pm 1.69 *$ & $50.9 \pm 1.06 * *$ & 1.41 \\
\hline T. serrulatus $250 \mathrm{mg} / \mathrm{kg}$ & $95.6 \pm 1.87 * *$ & $60.4 \pm 1.11 * * *$ & 1.58 \\
\hline T. serrulatus $500 \mathrm{mg} / \mathrm{kg}$ & $91.5 \pm 1.44^{* *}$ & $53.3 \pm 1.38 * *$ & 1.71 \\
\hline T. serrulatus $1,000 \mathrm{mg} / \mathrm{kg}$ & $100.4 \pm 1.96^{* *}$ & $64.2 \pm 2.01 * * *$ & 1.56 \\
\hline
\end{tabular}

Notes: Cumulative values are expressed as mean \pm SEM. $* P<0.05, * * P<0.01$, $* * * P<0.001$.

Abbreviations: NS, normal saline; HCTZ, hydrochlorothiazide; SEM, standard error of mean. 
Table 5 Effect of the dichloromethane fraction of aqueous extract of Thymus serrulatus on the electrolyte excretion in mice

\begin{tabular}{llll}
\hline Treatment & \multicolumn{3}{l}{ Electrolyte concentration (mEq/L) } \\
\cline { 2 - 4 } & $\mathbf{N a}^{+}$ & $\mathbf{K}^{+}$ & $\mathbf{N a}^{+} / \mathbf{K}^{+}$ \\
\hline Control NS & $76.2 \pm 1.5 \mathrm{I}$ & $40.5 \pm 1.32$ & 1.87 \\
$\mathrm{HCTZ} 10 \mathrm{mg} / \mathrm{kg}$ & $97.9 \pm 1.25^{* *}$ & $45.6 \pm 1.28^{*}$ & 2.14 \\
T. serrulatus $125 \mathrm{mg} / \mathrm{kg}$ & $68.5 \pm 1.40$ & $43.7 \pm 0.78$ & 1.56 \\
T. serrulatus $250 \mathrm{mg} / \mathrm{kg}$ & $75.3 \pm 1.5 \mathrm{I}$ & $40.9 \pm 0.85$ & 1.84 \\
T. serrulatus $500 \mathrm{mg} / \mathrm{kg}$ & $76.3 \pm 1.03$ & $40.3 \pm 1.18$ & 1.89 \\
T. serrulatus $1,000 \mathrm{mg} / \mathrm{kg}$ & $76.0 \pm \mathrm{I} .67$ & $4 \mathrm{I} .5 \pm \mathrm{I} .33$ & 1.83 \\
\hline
\end{tabular}

Notes: Cumulative values are expressed as \pm mean SEM. $* P<0.05$, **P<0.0I. Abbreviations: NS, normal saline; HCTZ, hydrochlorothiazide; SEM, standard error of mean.

Table 6 Effect of the $n$-butanol fraction of aqueous extract of Thymus serrulatus on the electrolyte excretion in mice

\begin{tabular}{|c|c|c|c|}
\hline \multirow[t]{2}{*}{ Treatment } & \multicolumn{3}{|c|}{ Electrolyte concentration (mEq/L) } \\
\hline & $\mathbf{N a}^{+}$ & $\mathbf{K}^{+}$ & $\mathrm{Na}^{+} / \mathbf{K}^{+}$ \\
\hline Control NS & $70.2 \pm 1.27$ & $45.5 \pm 1.30$ & 1.54 \\
\hline HCTZ 10 mg/kg & $113.5 \pm 1.48^{* * * *}$ & $53.5 \pm 1.42 *$ & 2.12 \\
\hline T. serrulatus $125 \mathrm{mg} / \mathrm{kg}$ & $87.4 \pm 1.06 * *$ & $50.0 \pm 1.23^{*}$ & 1.74 \\
\hline T. serrulatus $250 \mathrm{mg} / \mathrm{kg}$ & $115.2 \pm 1.34 * * *$ & $64.9 \pm 1.5 I^{* *}$ & 1.77 \\
\hline T. serrulatus $500 \mathrm{mg} / \mathrm{kg}$ & $92.7 \pm 1.16^{* *}$ & $58.1 \pm 1.0 I^{* *}$ & 1.59 \\
\hline T. serrulatus $1,000 \mathrm{mg} / \mathrm{kg}$ & $112.8 \pm 1.55^{* * * *}$ & $69.4 \pm 1.7 I^{* *}$ & 1.62 \\
\hline
\end{tabular}

Notes: Cumulative values are expressed as mean \pm SEM. $* P<0.05, * * P<0.01$, $* * * P<0.001$.

Abbreviations: NS, normal saline; HCTZ, hydrochlorothiazide; SEM, standard error of mean; $X$, mean.

the urinary excretion of $\mathrm{Na}^{+}$and $\mathrm{K}^{+}(P<0.001$ and $P<0.01$, respectively) at all doses (Table 6). This fraction at the dose of $1,000 \mathrm{mg} / \mathrm{kg}$ exhibited the highest natriuretic activity and a higher kaliuretic activity than HCTZ.

\section{Acute toxicity test}

Since the acute toxicity profile of the aqueous crude extract had already been determined using the limit test by Debelo et $a 1,{ }^{13}$ it was only necessary to determine the acute toxicity profile of the $n$-butanol fraction (the most active solvent fraction). The animals showed no clinical signs of toxicity and overt behavioral changes at the oral limit dose of 5,000 $\mathrm{mg} / \mathrm{kg}$ of $n$-butanol fraction of the aqueous crude extract. Also, no mortality was seen during the observation period.

\section{Phytochemical screening}

Basic investigations of the extracts for their major phytocompounds are vital as the active principles of many drugs are these secondary metabolites found in plants. The various phytochemical screening tests performed on the crude extracts and solvent fractions $T$. serrulatus leaves revealed the presence of different secondary metabolites (Table 7).

\section{Discussion}

Numerous mono- and polyherbal preparations are used as diuretics. There are also a number of studies that have been carried out to support the diuretic effects of many traditional herbal medicines. ${ }^{14}$ Thyme tea is consumed for the management of both renal diseases and hypertension, and the tea is prepared by soaking the fresh leaves of $T$. serrulatus in warm water, following which the filtrate is drunk. ${ }^{15}$ The in vitro vasodilatory activity of the aqueous crude extract in both intact and denuded guinea pig aorta was reported by Geleta et al. ${ }^{6}$ On the other hand, the acute and subchronic toxicity study reported that the aqueous crude extract has $\mathrm{LD}_{50}>10$ $\mathrm{g} / \mathrm{kg}$ and was safe in mice. ${ }^{13}$ However, there is no scientific report on the diuretic activity of the plant. In view of these facts, the present study attempted to corroborate the diuretic effect of the crude aqueous extract of the leaves of $T$. serrulatus and its solvent fractions at different doses.

The outcome of the present study implies that the crude aqueous extract of the leaves of T. serrulatus and its $n$-butanol fraction both have a diuretic action at all doses, further substantiating its use for hypertension. The results also illustrate that the aqueous crude extract and the $n$-butanol fraction increased urinary excretion of both sodium and potassium significantly.

The $\mathrm{Na}^{+} / \mathrm{K}^{+}$ratio can predict the nature of the diuretic mechanism. ${ }^{16} \mathrm{~A} \mathrm{Na}^{+} / \mathrm{K}^{+}$ratio of $>1$ indicates a satisfactory

Table 7 Phytochemical screening of aqueous crude extracts and solvent fractions of Thymus serrulatus leaves

\begin{tabular}{|c|c|c|c|c|c|c|c|c|c|}
\hline Type of extract & Alkaloids & Saponins & Polyphenols & Flavonoids & Terpenoids & Anthraquinones & Tannins & Phytosterols & $\begin{array}{l}\text { Cardiac } \\
\text { glycosides }\end{array}$ \\
\hline Aqueous crude & + & + & + & - & - & - & + & + & - \\
\hline $\begin{array}{l}\text { Dichloromethane } \\
\text { fraction }\end{array}$ & - & + & - & + & - & - & + & + & - \\
\hline$n$-Butanol fraction & + & + & + & - & - & - & + & + & - \\
\hline $\begin{array}{l}\text { Negative control } \\
\text { (vehicle) }\end{array}$ & - & - & - & - & - & - & - & - & - \\
\hline
\end{tabular}

Notes: +, present; -, absent. 
diuresis without excessive urinary potassium loss. ${ }^{17}$ The plant material does not seem to be a potassium sparing diuretic as the $\mathrm{Na}^{+} / \mathrm{K}^{+}$ratio in all cases was found to be $>1$.

The dichloromethane fraction of the aqueous extract did not result in a significant diuresis as well as electrolyte excretion at all given doses. This suggests that most of the nonpolar components of this plant may not have diuretic activity. Moreover, the disproportional dose-response correlation that was evident with the crude extract's urinary excretion might be due to the presence of various phytoconstituents, which might interact with each other or possibly interfere with the absorption, distribution, or binding to the receptor of the active components present in the extract.

The lowest test dose of the crude aqueous extract $(125 \mathrm{mg} / \mathrm{kg}$ ) failed to show diuretic effect perhaps due to the low concentration of the active principle(s) present in the extract. From these observations, one can only suggest that high doses of crude aqueous extracts of $T$. serrulatus as well as its $n$-butanol fraction have substantial diuretic activity. The essential oil of the leaves of T. serrulatus was found to contain $p$-cymene $(13 \%), \gamma$-terpinene $(13 \%)$, and thymol (49\%) as major components. ${ }^{18}$ The pharmacological activities of the plant are mainly attributed to its thymol content, which is an monoterpene phenolic compound. ${ }^{19}$ The phytochemical screening of the powdered dried leaves of $T$. serrulatus revealed the presence of alkaloids, tannins, saponins, and phytosterols. ${ }^{20}$ Phenolic compounds are secondary metabolites that are known to have a significant diuretic activity. ${ }^{21,22}$ The superiority of diuretic activity of the $n$-butanol fraction as compared to the crude extract can possibly be attributed to the relative higher solubility of the active phytoconstituent(s) in alcohols. ${ }^{23,24}$ From this study, however, the exact components responsible for the observed activity of the plant cannot be confirmed.

\section{Conclusion}

As evidenced by the outcome of this study, it is reasonable to infer that the crude aqueous extract of $T$. serrulatus leaves and its $n$-butanol fraction possess a significant diuretic activity in mice. Further in-depth studies are required to assess the diuretic activity of other crude extracts of the leaves of T. serrulatus and to elucidate possible mechanism of action. Moreover, efforts should also be geared toward identifying the specific phytochemicals responsible for the observed activity.

\section{Acknowledgments}

The authors are thankful for the financial support provided by the School of Graduate Studies of Addis Ababa University and Ministry of Finance and Economic Development through EPHI. They also would like to thank the staff of the Directorate of Traditional and Modern Medicine Research for their assistance during the study.

\section{Disclosure}

The authors report no conflicts of interest in this work.

\section{References}

1. World Health Organization. Traditional Medicine Strategy: 2014-2023. Geneva, Switzerland: World Health Organization; 2013.

2. Pizzi RA. Developing diuretics from mercurials to the thiazides, these "urine promoters" have proved to be some of the most prescribed therapeutics. Modern Drug Discov. American Chemical Society. 2003:10-20.

3. Qavi AH, Kamal R, Schrier RW. Clinical use of diuretics in heart failure, cirrhosis, and nephrotic syndrome. Int J Nephrol. 2015;2015:975934.

4. Vazir1 A, Cowie MR. The use of diuretics in acute heart failure: evidence based therapy? World J Cardiovasc Dis. 2013;3(3):25-34.

5. Tamargo J, Segura J, Ruilope LM. Diuretics in the treatment of hypertension. Part 1: thiazide and thiazide-like diuretics. Expert Opin Pharmacother. 2014;15(4):527-547.

6. Geleta B, Eyasu M, Kamo S, Debella A, Mekonnen E, Abebe A. In vitro vasodilatory effect of aqueous leaf extract of Thymus serrulatus on thoracic aorta of Guniea pigs. Asian Pac JTrop Biomed. 2015;5(1):15-18.

7. Damtie D, Mekonnen Y. Thymus species in Ethiopia: distribution, medicinal value, economic benefit, current status and threatening factors. Ethiop J Sci Technol. 2015;8(2):81-92.

8. Demissew S. The Genus Thymus (Labiatae) in Ethiopia opera Bot. (ALNAP Database Ref. ID: 3896) 1993;121:57-60.

9. Kau ST, Keddie JR, Andrews D. A method for screening diuretic agents in the rat. J Pharmacol Methods. 1984;11(1):67-75.

10. Vogel GH, Vogel WH, Scholkens BA, Sandow J, Muller G, Vogel WF. Drug discovery and evaluation. 3rd ed. In: Vogel H, editor. Pharmacological Assays. Berlin, Heidelberg: Springer; 2008.

11. OECD. Guidelines for the Testing of New Chemicals Revised Draft Guideline 423; Acute Oral Toxicity, 2008. Available from: http://ntp. niehs.nih.gov/iccvam/SuppDocs/FedDocs/OECD/OECDtg425.pdf. Accessed July 14, 2016.

12. Trease GE, Evans WC. Pharmacognosy. 13th ed. London, UK: Bailliere Tindall; 1989:135-250.

13. Debelo N, Afework M, Debella A, Makonnen E, Ergete W, Geleta B. Histopathological and biochemical assessment of chronic oral administration of aqueous leaf extract of Thymus serrulatus in mice. J Clin Exp Pathol. 2015;5:258.

14. Dutta KD, Chetia P, Lahkar SS, Das S. Herbal plants used as diuretics: a comprehensive review. J Pharmaceut Chem Biol Sci. 2014;2(1):27-32.

15. Parvez N, Yadav S. Ethnopharmacology of single herbal preparations of medicinal plant in Asendabo district, Jimma Ethiopia. Indian J Tradit Knowl. 2010;9(4):724-729.

16. Toma CC, Olah NK, Vlase L, Mogoşan C, Mocan A. Comparative studies on polyphenolic composition, antioxidant and diuretic effects of Nigella sativa L. (black cumin) and Nigella damascena L. (lady-ina-mist) seeds. Molecules. 2015;20(6):9560-9574.

17. Alexander WD, Branch RA, Levine DF, Hartog M. The urinary sodium: potassium ratio and response to diuretics in resistant oedema. Postgrad Med J. 1977;53(617):117-121.

18. Asfaw N, Storesund HJ, Skattebol L, Tonnesen F, Aasen AJ. Volatile oil constituents of two Thymus species from Ethiopia. Flavour Fragr J. 2000;15:123-125.

19. Demissew S, Asfaw N. Somesseful indigenous labiates from Ethiopia. Lamiales Newslett. 1994;3:5-6.

20. Bekele A. Evaluation of the spasmolytic activity and safety of T. serrulatus in laboratory animals, 2006. Available from: http://etd.aau.edu.et/ bitstream/123456789/5658/1/11.\%20Addisu\%20bekele.pdf. Accessed June 16, 2016. 
21. Dearing MD, Mangione AM, Karasov WH. Plant secondary compounds as diuretics: an overlooked consequence. Am Zool. 2001;41(4) 890-901.

22. Quispe C, Viveros-Valdez E, Schmeda-Hirschmann G. Phenolic constituents of the chilean herbal tea Fabiana imbricata R. et P. Plant Foods Hum Nutr. 2012;67(3):242-246.
23. Bermejo VD, Angelov I, Vicente G, et al. Extraction of thymol from different varieties of thyme plants using green solvents. J Sci Food Agric. 2015;95(14):2901-2907.

24. NIH. National Center for Biotechnology Information. PubChem Compound Database; $\mathrm{CID}=6989$. Available from: https://pubchem.ncbi.nlm. nih.gov/compound/6989. Accessed June 28, 2016.
Journal of Experimental Pharmacology

\section{Publish your work in this journal}

The Journal of Experimental Pharmacology is an international, peerreviewed, open access journal publishing original research, reports reviews and commentaries on all areas of laboratory and experimental pharmacology. The manuscript management system is completely online and includes a very quick and fair peer-review system.

Submit your manuscript here: https://www.dovepress.com/journal-of-experimental-pharmacology-journal 